\title{
Estimation of Optimum Alum Doses of Mountain Water for Water Supply Treatment in Hill Tribe Villages in Chiang Rai Province, Thailand
}

Suntorn Sudsandee ( $\square$ suntorn.sud@mfu.ac.th )

School of Health Science Mae Fah Luang University https://orcid.org/0000-0002-4557-189X

Natthathida Patthanacheroen

National Institute of Development Administration

\section{Research Article}

Keywords: Hill trbe, Mountin Water, Jar Test, Turbidity, Potassium Alum, Optimum Alum Dose.

Posted Date: September 13th, 2021

DOI: https://doi.org/10.21203/rs.3.rs-767281/v1

License: (c) (1) This work is licensed under a Creative Commons Attribution 4.0 International License.

Read Full License 


\section{Abstract}

Hill tribe villages are located in mountainous and remote areas. Primary water supply and drinking water sources are mountain water from a small weir on the mountain. Most mountain waters found turbidity higher than 1 NTU, and water quality was unclean to use and drink. This research applied different concentrations of alum doses to observe turbidity reduction. Optimum alum does apply to reduce turbidity for mountain water samples from Hmong, Karen, Lahu, and Lisu for three seasons. The optimum alum dose is between $20-40 \mathrm{mg} / \mathrm{l}$ in rainy seasons and $10-40 \mathrm{mg} / \mathrm{l}$ in summer. The cold season was low optimum alum dose at $10 \mathrm{mg} / \mathrm{l}$ for all hill tribe villages. Therefore, alum coagulants can be used to treat the mountain water supply and drinking that can implement the main problem of mountain water in hill tribe village.

\section{Introduction}

Hill tribe villages are located in the mountainous area in Northern Thailand. The hill tribes in Thailand are divided into six main groups, Akha, Hmong, Karen, Lahu, Lisu, and Yao. Each hill tribe groups have they language, culture, and beliefs, which are different from the Thai people. Most hill tribes live in the mountainous border areas and remote areas difficult to accessed government facilities such as water supply, electricity, and health care service.

The mountain water is a primary source to use in hill tribe villages in northern, Thailand. To build the concrete or soil weirs were used for storing mountain water. The water was supplied through polyvinyl chloride (PVC) or steel pipes that distribute to households in hill tribe villages. Therefore, mountain water has been using in hill tribe villages that are without treatment. Poor-quality water supply and drinking water was found exceeding of World Health Organization (WHO) standard such as coliform bacteria and fecal coliform bacteria, turbidity, iron, color, and $\mathrm{pH}$ and found high turbidity about $36 \%$ of drinking water (Sudsandee et al. 2021). The turbidity of the colloids in water is the small particle in water that cannot be settled or removed naturally due to their light and stability (Baghvand et al., 2010). The stability of particles in natural water depends on a balance between the repulsive electrostatic force of the particles and the attractive forces known as the van der Waals forces.

Since particles in water have a net negative surface charge, the principal mechanism controlling particle stability is electrostatic repulsion (Hand et al., 2012). The turbidity is a physical property of water that determines drinking water and water supply standards (WHO, 2011; Department of Health, 2010; MWA, 2021). Therefore, a water treatment plant can reduce the turbidity by using a coagulant or alum. As these chemicals hydrolyze, they form insoluble precipitates that destabilize particles by adsorbing to the surface of the particles and neutralizing the charge (thus reducing the repulsive forces). Selection of the type and dose of coagulant depends on the characteristics of the coagulant, the concentration and type of particles, concentration and characteristics of natural organic matter (NOM), water temperature, and water quality. 
Coagulants are chemicals that are used to assist with the removal of turbidity present in untreated raw water such as aluminum sulfate $\left(\mathrm{Al}_{2}\left(\mathrm{SO}_{4}\right) 318 \mathrm{H} 20\right)$, polyaluminium chloride $\left(\mathrm{Al}_{2}(\mathrm{OH})_{3} \mathrm{Cl}_{3}\right)$, and ferric chloride $\left(\mathrm{FeCl}_{3}\right)$. The coagulants do this by forming settleable particles in the form of flocs, which are then removed in downstream clarification or filtration treatment processes. Alum is the first coagulant of selection because of its lower cost and its worldwide availability (Baghvand et al., 2010). Jar test of standard practice for coagulation-flocculation of raw water is a practice for the evaluation of a treatment to reduce dissolved, suspended, colloidal, and unsettle mater from coagulants, followed by gravity settling (ASTM, 1995). The Jar test is a common laboratory procedure used to determine the optimum dose of different coagulants or alum, on a small scale to predict the functioning of large-scale treatment operating conditions for water or wastewater treatment. Jar testing aims to determine the amount of coagulant dosage and to determine appropriate conditions for water treatment plants operation. Many researchers have applied the Jar test experient to estimate coagulant to treat water (Baghvand et al., 2010, León-Luque et al., 2016, Saritha et al., 2017, Zainal-Abideen et al., 2012, Lanciné et al., 2008).

Therefore, the optimum alum dose is the amount of alum to apply in the water treatment plant to assist particles to settle on the basin. The effectiveness of the coagulation process in a water treatment plant is highly dependent on many factors, including the dosage of coagulant and coagulant aids and also $\mathrm{pH}$ of operation. This study aims to find the optimum alum dose of mountain water of hill tribe village.

Mountain water is a primary source has been found high turbidity exceeded the water supply and drinking water standard and alum can reduce the turbidity what is the main problem of mountain water supply.

\section{Methadology}

\subsection{Study sites and sampling stations}

The hill tribe villages are located in Chiang Rai Province in northern Thailand which all use mountain water and drink mountain water. There are four water sampling stations in Hmong, Karen, Lahu, and Lisu villages, which are located in the mountainous area remote area. The Hmong tribe villages (N20 02'43.74" E099 $53^{\circ} 38.27^{\prime \prime}$ and 810 masl) are located in the Chiang Khong district, while the Lahu $\left(20^{\circ} 03.142^{\prime} 56.44^{\prime \prime} \mathrm{E} 099^{\circ} 49.458^{\prime} 57.89^{\prime \prime}\right.$ and $570 \mathrm{masl}$ ) and Karen tribe villages (N1958'42.68" E099 ${ }^{\circ} 41^{\prime} 52.88^{\prime \prime}$ and 451 masl) are located in the Muang District of Chiang Rai Province. The Lisu villages ( $\mathrm{N} 20^{\circ} 21^{\prime} 55.48^{\prime \prime} \mathrm{E} 099^{\circ} 28^{\prime} 11.50^{\prime \prime}$ and 1,232 masl) are located close to the Thai-Myanmar border in the Mae Fah Luang District.

\subsection{Mountin water sampling and analysis}

A total of 12 mountain water samples were collected by a grab sampling technique from the weir of mountain water in four hill tribe villages consist of 4 samples from summer, 4 samples for the rainy season, and 4 samples for the cold season in 2019. Polyethylene (PE) bottles were utilized to collect the water samples from the weir of mountain water points. A total of seven liters of water samples were in PE bottles which were chilled at $4^{\circ} \mathrm{C}$ in an icebox until use for Jar test experiment within 72 hours. To device, 
one liter of water was employed to measure turbidity, total dissolved solids (TDS), and pH. For six-liter of mountain water was prepared to experiment with the Jar test method. The turbidity was measured by a turbidity meter (Turb 43 IE, WTW, Wissenschaftlish, Weiheim, Germany). The pH was measured by a pH meter (pH 34i SET 2, WTW, Wissenschaftlish, Weinheim, Germany). The TDS were determined by filtering water through filter paper (pore size of $0.45 \mu \mathrm{m}$ ) and were measured by a TDS meter (TDSTestr11, Waterproof, Oakton, USA).

\subsection{Jar test}

Measured qual volume at one liter of mountain water in each beaker NO. 1-6, and moved the beakers to the Jar Test machine. Then weighed the coagulant (Alum: Potassium alum (KAI(SO $) \otimes \cdot 12 \mathrm{H} \otimes \mathrm{O}$ ) $10 \mathrm{mg}$, $30 \mathrm{mg}, 40 \mathrm{mg}, 50 \mathrm{mg}$, and $60 \mathrm{mg}$ by using a digital balance. Turn on of Jar test machine by started the "flash mix" speed of approximately $100 \mathrm{rpm}$ for 1 minute. Added the fine solid alum 10-60 mg, at predetermined dosage levels and sequence beaker 1-6. Reduced the speed to keep floc particles uniformly suspended throughout the "slow mix" period. The slow mix for $30 \mathrm{rpm}$ for 30 minutes. After the slow mix period, turn off the Jar test machine and observe the settling of floc particles. Finally, measured the turbidity, pH, and TDS from each jar test a point one-half of the depth of samples (ASTM, 1995). The expected optimum alum dose must decrease the turbidity cut-off set at 1.0 NTU follow to the water supply standard of the Metropolitan Waterwork Authority, MWA, in Thailand (MWA, 2021).

\subsection{Data analysis}

A statistical analysis was performed by using SPSS version 24.0 software (SPSS version 24 (SPSS, Chicago, IL). The Kolmogorov-Smirnov test was performed to check the normality of data. Spearman correlation was used to assess the correlations of the mountain water qualities. The level of significance was set to $a=0.01$ and 0.05 , respectively.

\section{Results}

\subsection{Estimation of optimum alum doses}

\section{Hmong}

The mountain water was sampling raw water for six liters from a weir on-mountain in summer, rainy, and cold seasons in 2019. Then we measured the turbidity, TDS, and pH of mountain water. In summer, the quality of mountain water, that found 1.47 NTU for turbidity, $90 \mathrm{mg} / \mathrm{l}$ for TDS, and $7.88 \mathrm{for} \mathrm{pH}$. In rainy seasons, the quality of mountain water was found that 4.10 NTU for turbidity, $60 \mathrm{mg} / \mathrm{l}$ for TDS, and 8.57 for $\mathrm{pH}$. Finally, in the cold season found $1.30 \mathrm{NTU}, 70 \mathrm{mg} / \mathrm{l}$ for TDS, and $8.07 \mathrm{for} \mathrm{pH}$. Comparison of the turbidity of mountain water among three seasons found that the turbidity of rainy season $>$ summer season > cold season as shown in Fig. 1.

Jar test experiment, we added various alum concentrations from $10 \mathrm{mg} / \mathrm{l}$ to $60 \mathrm{mg} / \mathrm{l}$ in mountain water. Alum concentrations at $10 \mathrm{mg} / \mathrm{l}, 20 \mathrm{mg} / \mathrm{l}, 30 \mathrm{mg} / \mathrm{l}, 40 \mathrm{mg} / \mathrm{l}, 50 \mathrm{mg} / \mathrm{l}$, and $60 \mathrm{mg} / \mathrm{l}$ reduced the turbidity to 
0.88 NTU, 1.11 NTU, 0.94 NTU, 0.91 NTU, 0.90 NTU, and 0.62 NTU, respectively, from 1.47 NTU of mountain water in summer season as shown in Fig. 1. In addition, Alum concentrations from $10 \mathrm{mg} / \mathrm{I}$ to $60 \mathrm{mg} / \mathrm{l}$ reduced the turbidity to $1.33 \mathrm{NTU}, 1.50 \mathrm{NTU}, 0.97 \mathrm{NTU}, 0.74 \mathrm{NTU}, 0.98 \mathrm{NTU}$, and 0.92 NTU, respectively, from 4.10 NTU of mountain water in the rainy season. Finally, Alum concentrations from 10 $\mathrm{mg} / \mathrm{l}$ to $60 \mathrm{mg} / \mathrm{l}$, all samples reduced the turbidity to $0.01 \mathrm{NTU}$ from $1.30 \mathrm{NTU}$ of mountain water in the cold season.

Figure 5 was the result of optimum alum dose for mountain water in Hmong village. The appropriately dose used in the rainy season was $30 \mathrm{mg} / \mathrm{l}$. Both summer and cold seasons were using for $10 \mathrm{mg} / \mathrm{l}$. In the rainy season of alum concentration use in water treatment was higher than in summer and cold seasons.

\section{Karen}

The mountain water was sampling raw water for six liters from a weir on-mountain in summer, rainy, and cold seasons in 2019. Then we measured the turbidity, TDS, and pH of mountain water. In summer, the quality of mountain water, that found $4.30 \mathrm{NTU}$ for turbidity, $90 \mathrm{mg} / \mathrm{l}$ for TDS, and $8.67 \mathrm{for} \mathrm{pH}$. In rainy seasons, the quality of mountain water was found that 5.41 NTU for turbidity, $100 \mathrm{mg} / \mathrm{l}$ for TDS, and 7.19 for $\mathrm{pH}$. Finally, in the cold season found $0.47 \mathrm{NTU}, 80 \mathrm{mg} / \mathrm{l}$ for TDS, and $8.01 \mathrm{for} \mathrm{pH}$. Comparison of the turbidity of mountain water among three seasons found that the turbidity of rainy season $>$ summer season > cold season as shown in Fig. 2.

Jar test experiment, we added various alum concentrations from $10 \mathrm{mg} / \mathrm{l}$ to $60 \mathrm{mg} / \mathrm{l}$ in mountain water. Alum concentrations at $10 \mathrm{mg} / \mathrm{l}, 20 \mathrm{mg} / \mathrm{l}, 30 \mathrm{mg} / \mathrm{l}, 40 \mathrm{mg} / \mathrm{l}, 50 \mathrm{mg} / \mathrm{l}$, and $60 \mathrm{mg} / \mathrm{l}$ reduced the turbidity to 1.20 NTU, 1.57 NTU, 0.96 NTU, 0.64 NTU, 0.68 NTU, and 0.80 NTU, respectively, from 4.30 NTU of mountain water in summer season as shown in Fig. 2. In addition, Alum concentrations from $10 \mathrm{mg} / \mathrm{l}$ to $60 \mathrm{mg} / \mathrm{l}$ reduced the turbidity to $4.15 \mathrm{NTU}, 4.30 \mathrm{NTU}, 1.20 \mathrm{NTU}, 0.90 \mathrm{NTU}, 0.86 \mathrm{NTU}$, and 0.88 NTU, respectively, from 5.41 NTU of mountain water in the rainy season. Finally, Alum concentrations from 10 $\mathrm{mg} / \mathrm{l}$ to $60 \mathrm{mg} / \mathrm{l}$, all samples reduced the turbidity to $0.21 \mathrm{NTU}$ for alum $10 \mathrm{mg} / \mathrm{l}, 0.01 \mathrm{NTU}$ for alum 20$60 \mathrm{mg} / \mathrm{l}$ which all reduced from $1.30 \mathrm{NTU}$ of mountain water in the cold season.

Figure 5 was the result of optinum alum dose for mountain water in Karen village. The appropriately alum dose used in the rainy season was $40 \mathrm{mg} / \mathrm{l}$. In summer, the The appropriately alum dose was $30 \mathrm{mg} / \mathrm{l}$, and in cold season was $10 \mathrm{mg} / \mathrm{l}$ of alum dose. Comparison of appropriately alum doses among three seasons found that the alum doses of rainy season > summer season > cold season.

\section{Lahu}

The mountain water was sampling raw water for six liters from a weir on-mountain in summer, rainy, and cold seasons in 2019. Then we measured the turbidity, TDS, and pH of mountain water. In summer, the quality of mountain water, that found 5.44 NTU for turbidity, $70 \mathrm{mg} / \mathrm{l}$ for TDS, and $6.96 \mathrm{for} \mathrm{pH}$. In rainy seasons, the quality of mountain water was found that 7.22 NTU for turbidity, 60 mg/l for TDS, and 7.55 
for $\mathrm{pH}$. Finally, in the cold season found $2.35 \mathrm{NTU}, 70 \mathrm{mg} / \mathrm{l}$ for TDS, and $7.96 \mathrm{for} \mathrm{pH}$. Comparison of the turbidity of mountain water among three seasons found that the turbidity of rainy season > summer season > cold season as shown in Fig. 3.

Jar test experiment was added various alum concentrations from $10 \mathrm{mg} / \mathrm{l}$ to $60 \mathrm{mg} / \mathrm{l}$ in mountain water. Alum concentrations at $10 \mathrm{mg} / \mathrm{l}, 20 \mathrm{mg} / \mathrm{l}, 30 \mathrm{mg} / \mathrm{l}, 40 \mathrm{mg} / \mathrm{l}, 50 \mathrm{mg} / \mathrm{l}$, and $60 \mathrm{mg} / \mathrm{l}$ reduced the turbidity to 1.11 NTU, 1.45 NTU, 2.11 NTU, 0.67 NTU, 0.96 NTU, and 0.73 NTU, respectively, from 5.44 NTU of mountain water in summer season as shown in Fig. 3. In addition, Alum concentrations from $10 \mathrm{mg} / \mathrm{l}$ to $60 \mathrm{mg} / \mathrm{l}$ reduced the turbidity to $2.75 \mathrm{NTU}, 2.63 \mathrm{NTU}, 2.34 \mathrm{NTU}, 0.83 \mathrm{NTU}, 0.71 \mathrm{NTU}$, and $1.02 \mathrm{NTU}$, respectively, from $7.22 \mathrm{NTU}$ of mountain water in the rainy season. Finally, added alum concentrations from $10 \mathrm{mg} / \mathrm{l}$ to $60 \mathrm{mg} / \mathrm{l}$, the turbidity reduced to $0.63 \mathrm{NTU}$ for alum $10 \mathrm{mg} / \mathrm{l}, 0.39 \mathrm{NTU}$ for alum $20 \mathrm{mg} / \mathrm{l}$, 0.01 NTU for alum 30-60 mg/l, which all reduced from 0.47 NTU of mountain water in the cold season.

Figure 5 was the result of optinum alum dose for mountain water in Lahu village. The appropriately alum dose used in the rainy and summer seasons were $40 \mathrm{mg} / \mathrm{l}$. In cold season, the the appropriately alum dose was $10 \mathrm{mg} / \mathrm{l}$. Comparison of appropriately alum doses among three seasons found that the alum doses of rainy season $=$ summer season $>$ cold season .

\section{Lisu}

The mountain water was sampling raw water for six liters from a weir on-mountain in summer, rainy, and cold seasons in 2019. Then we measured the turbidity, TDS, and pH of mountain water. In summer, the quality of mountain water, that found 5.61 NTU for turbidity, $30 \mathrm{mg} / \mathrm{l}$ for TDS, and $8.39 \mathrm{for} \mathrm{pH}$. In rainy seasons, the quality of mountain water was found that 4.01 NTU for turbidity, $30 \mathrm{mg} / \mathrm{l}$ for TDS, and 8.37 for $\mathrm{pH}$. Finally, in the cold season found $2.80 \mathrm{NTU}, 30 \mathrm{mg} / \mathrm{l}$ for TDS, and $7.65 \mathrm{for} \mathrm{pH}$. Comparison of the turbidity of mountain water among three seasons found that the turbidity of summer season $>$ rainy season > cold season as shown in Fig. 4.

Jar test experiment, we added various alum concentrations from $10 \mathrm{mg} / \mathrm{l}$ to $60 \mathrm{mg} / \mathrm{l}$ in mountain water. Alum concentrations at $10 \mathrm{mg} / \mathrm{l}, 20 \mathrm{mg} / \mathrm{l}, 30 \mathrm{mg} / \mathrm{l}, 40 \mathrm{mg} / \mathrm{l}, 50 \mathrm{mg} / \mathrm{l}$, and $60 \mathrm{mg} / \mathrm{l}$ reduced the turbidity to 1.15 NTU, 0.79 NTU, 0.70 NTU, 1.42 NTU, 2.28 NTU, and 2.05 NTU, respectively, from 5.61 NTU of mountain water in summer season as shown in Fig. 4. In addition, Alum concentrations from $10 \mathrm{mg} / \mathrm{I}$ to $60 \mathrm{mg} / \mathrm{I}$ reduced the turbidity to $1.26 \mathrm{NTU}, 0.84 \mathrm{NTU}, 0.68 \mathrm{NTU}, 1.95 \mathrm{NTU}, 2.09 \mathrm{NTU}$, and $1.91 \mathrm{NTU}$, respectively, from 4.01 NTU of mountain water in the rainy season. Finally, Alum concentrations from 10 $\mathrm{mg} / \mathrm{l}$ to $60 \mathrm{mg} / \mathrm{l}$, all samples reduced the turbidity to 0.01 for alum $10-60 \mathrm{mg} / \mathrm{l}$ which all reduced from 2.80 NTU of mountain water in the cold season.

Figure 5 was the result of optinum alum dose for mountain water in Lisu village. The appropriately alum dose used in the rainy season and summer were $20 \mathrm{mg} / \mathrm{l}$. In cold season, the the appropriately alum dose was $10 \mathrm{mg} / \mathrm{l}$. Comparison of appropriately alum doses among three seasons found that the alum doses of rainy season $=$ summer season $>$ cold season . 
Our studies applied alum in form of potassium alum (KAI(SO $)$ $\Downarrow \cdot 12 \mathrm{H} \otimes 0$ ) which is the difference from previous studies (Baghvand et al., 2010, Lanciné et al., 2008 Zainal-Abideen et al., 2012, León-Luque et al., 2016, Saritha et al., 2017). Table 1 shows optimum coagulant doses 10-14 mg/l for turbidity 1.307.22 NTU. The mountain water was raw water samples which low turbidity than other surface waters for Jar test experiments (Lanciné et al., 2008, Baghvand et al., 2010, León-Luque et al., 2016, Saritha et al., 2017). The optimum coagulant doses of raw water used between $12-300 \mathrm{mg} / \mathrm{l}$ which depended on raw water types, coagulant types, quality of raw water such as $\mathrm{pH}$, temperature, natural organic matters (NOM) (Hand et al, 2012).

\subsection{Correlations of alum doses and water qualities}

The alum concentrations doses added in 10-60 mg/l of mountain water had a slightly positive correlation with TDS $[r=0.29$ ( $p$-value $<0.050)]$ as shown in Table 2. TDS is a measure of the dissolved combined content of all inorganic and organic substances present in a liquid in molecular, ionized, or micro-granular, suspended form (Stuetz, 2009). TDS concentrations are often found high concentration when alum was high concentration in raw water. In contrast, the alum concentration doses had a slightly negative correlation with $\mathrm{pH}[\mathrm{r}=-0.40(\mathrm{p}=$ value $<0.010)]$. Thus, adding alum is like adding a strong acid. A strong acid will lower the $\mathrm{pH}$ (Hand et al., 2012).

Table 1

Literature reviews of coagulant types and raw water

\begin{tabular}{|c|c|c|c|c|}
\hline Coagulant types & Raw water types & $\begin{array}{l}\text { Quality } \\
\text { of raw } \\
\text { water }\end{array}$ & $\begin{array}{l}\text { Optimum } \\
\text { coagulant doses } \\
(\mathrm{mg} / \mathrm{l})\end{array}$ & References \\
\hline $\begin{array}{l}\text { Potassium alum } \\
\text { (KAl (SO }) \bowtie \cdot 12 \mathrm{H} \bowtie \mathrm{O})\end{array}$ & $\begin{array}{l}\text { Mountain water from hill } \\
\text { tribe village }\end{array}$ & $\begin{array}{l}1.30- \\
7.22 \mathrm{NTU}\end{array}$ & $10-40 \mathrm{mg} / \mathrm{l}$ & This study \\
\hline $\begin{array}{l}\text { Aluminium sulphate } \\
\mathrm{Al}_{2}\left(\mathrm{SO}_{4}\right)_{3}\end{array}$ & Water reservoir & $\begin{array}{l}15.10 \\
\text { NTU }\end{array}$ & 100 mg/l & $\begin{array}{l}\text { Lanciné et } \\
\text { al., } 2008\end{array}$ \\
\hline $\begin{array}{l}\text { Aluminum sulfate }\left(\mathrm{Al}_{2}\right. \\
\left.\left(\mathrm{SO}_{4}\right)_{3} \cdot 18 \mathrm{H}_{2} \mathrm{O}\right) \text { and } \\
\text { ferric chloride }\left(\mathrm{FeCl}_{3} \text {. }\right. \\
\left.6 \mathrm{H}_{2} \mathrm{O}\right)\end{array}$ & $\begin{array}{l}\text { Initial turbidities of water } \\
\text { samples in laboratory }\end{array}$ & 100 NTU & $40-50 \mathrm{mg} / \mathrm{l}$ & $\begin{array}{l}\text { Baghvand et } \\
\text { al., } 2010\end{array}$ \\
\hline $\begin{array}{l}\text { Alum (liquid aluminium } \\
\text { sulphate) and polymer }\end{array}$ & $\begin{array}{l}\text { Raw water from Sri- } \\
\text { Gading water treatment } \\
\text { plant }\end{array}$ & 5.46 NTU & 12 mg/l & $\begin{array}{l}\text { Zainal- } \\
\text { Abideen et } \\
\text { al., } 2012\end{array}$ \\
\hline $\begin{array}{l}\text { Aluminum sulfate }\left(\mathrm{Al}_{2}\right. \\
\left.\left(\mathrm{SO}_{4}\right) 318 \mathrm{H}_{2} \mathrm{O}\right)\end{array}$ & River & $\begin{array}{l}15-950 \\
\text { NTU }\end{array}$ & $22-90 \mathrm{mg} / \mathrm{l}$ & $\begin{array}{l}\text { León-Luque } \\
\text { et al., } 2016\end{array}$ \\
\hline $\begin{array}{l}\text { Indian sago starch and } \\
\text { Chitin }\end{array}$ & Surface water & 100 NTU & $100-300 \mathrm{mg} / \mathrm{l}$ & $\begin{array}{l}\text { Saritha et al., } \\
2017\end{array}$ \\
\hline
\end{tabular}


Table 2

Correlations of alum doses and water qualities

\begin{tabular}{|lllll|}
\hline & Alum concentrations & Turbidity & TDS & pH \\
\hline Alum concentrations & 1 & & & \\
\hline Turbidity & -0.20 & 1 & & \\
\hline TDS & $0.29 *$ & -0.03 & 1 & \\
\hline pH & $-0.40 * *$ & 0.21 & -0.20 & 1 \\
\hline$*$ Correlation is significant at the 0.05 level (2-tailed). & & \\
\hline${ }^{* *}$ Correlation is significant at the 0.01 level (2-tailed). & & \\
\hline
\end{tabular}

\section{Conclusions}

The optimum alum does apply to reduce turbidity for mountain water samples from Hmong, Karen, Lahu, and Lisu for three seasons. The optimum alum dose is between $20-40 \mathrm{mg} / \mathrm{l}$ in rainy seasons and $10-40$ $\mathrm{mg} / \mathrm{l}$ in summer. The cold season was low optimum alum dose at $10 \mathrm{mg} / \mathrm{l}$ for all hill tribe villages. Therefore, alum coagulants can be used to treat the mountain water supply and drinking that can implement the main problem of mountain water in hill tribe village.

\section{Declarations}

\section{Acknowledgements}

We thank all hill tribes who allowed us for sampling of drinking water. We thank The National Research Council of Thailand (NRCT) and The Center of Excellence for the Hill-tribe Health Research of Mae Fah Luang University for their support via grants.

\section{Availability of data and materials}

The data are available upon the reasonable request to the corresponding author.

\section{Authors Contributions}

SS involved in conceptualization, laboratory analysis, writing - original draft, editing, and project administration. NP involved in data collection and laboratory analysis.

\section{Funding}

The study was funded by the National Research Council of Thailand (NRCT), (Grant No. $\mathbb{Q}(\mathbb{(})$ (㽖)/145/2561). 


\section{Ethical Approval}

Not applicable.

\section{Consent to Participate}

Not applicable.

\section{Consent to participate}

Not applicable.

\section{Consent to publish}

Not applicable.

\section{Consent to publish}

Not applicable.

\section{Competing Interests section}

Not applicable.

\section{References}

1. ASTM (1995) Standard practice for coagulation-flocculation jar test of Water E1-1994 R(1995), D 2035-80. Annual Book of ASTM Standards Vol. 11.02

2. Baghvand A, Zand AD, Mehrdadi N, Karbassi A (2010) Optimizing coagulation process for low to high turbidity waters using aluminum and iron salts. American Journal of Environmental Sciences 6 (5): 442-448, 2010. https://doi.org/10.3844/ajessp.2010.442.448

3. Department of Health, Thailand. Standard of Drinking Water from Water Supply System (2010) Available online: http://foodsan.anamai.moph.go.th/more_news.php?cid=87\&filename=index. (accessed on 20 October 2019) (In Thai)

4. Hand DW, Tchobanoglous G, Trussell RR, Crittenden JC, Howe KJ (2012) Principles of water treatment. (3rd ed., Student ed.) Wiley

5. Lanciné GD, Bamory K, Raymond L, Jean-luc S, Christelle B, Jean B (2008) Coagulation-flocculation treatment of a tropical surface water with alum for dissolved organic matter (DOM) removal: influence of alum dose and pH adjustment. J Int Environmental Application Science 3(4):247-257

6. León-Luque AJ, Barajas CL, Peña-Guzmán CA (2016) Determination of the optimal dosage of aluminum sulfate in the coagulation-flocculation process using an artificial neural network. International Journal of Environmental Science and Development 7 (5): 2016 
7. MWA (2021) Tap water standard of Metropolitan Waterwork Authority, MWA. Available online: https://www.mwa.co.th/ewt_dl_link.php?nid=33082. (accessed on 29 July 2021) (In Thai)

8. Sudsandee S, Fakkaew K, Siriratruengsuk W, Worakhunpiset S, Apidechkul T (2021) Quality of sources of drinking water and health among the hill tribe people of northern Thailand. Environ Geochem Health. 2021. https://doi.org/10.1007/s10653-021-00963-6

9. WHO (2011) Guidelines for Drinking-Water Quality, 4th ed.; WHO Graphics: Geneva, Switzerland, 2011

10. Zainal-Abideen M, Aris A, Yusof F, Abdul-Majid Z, Selamat A, Omar SI (2012) Optimizing the coagulation process in a drinking water treatment plant - comparison between traditional and statistical experimental design jar tests. Water Science \& Technology 65.3, 2012.

https://doi.org/10.2166/wst.2012.561

\section{Figures}

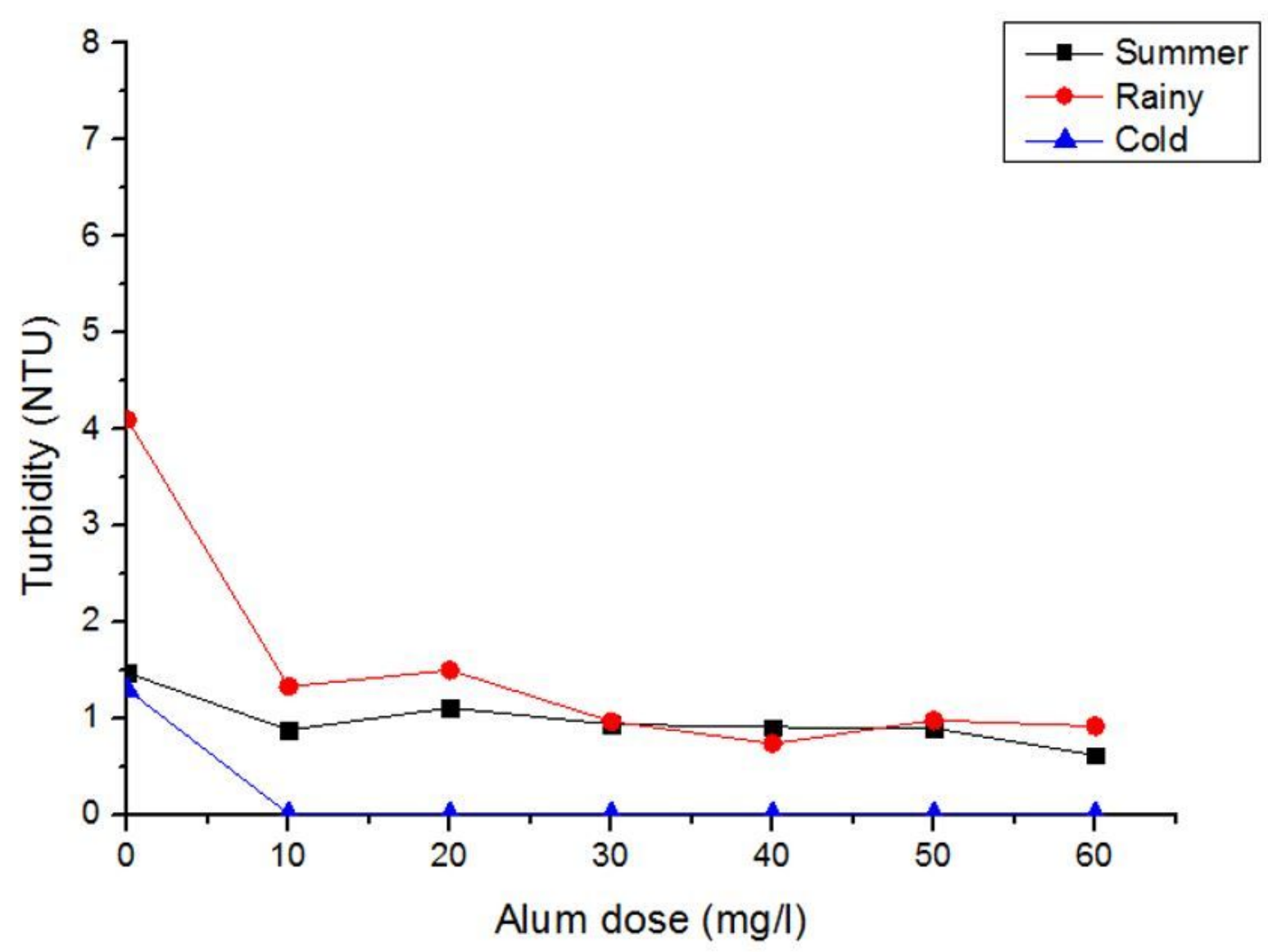

Figure 1

Jar test of mountain water from Hmong village 


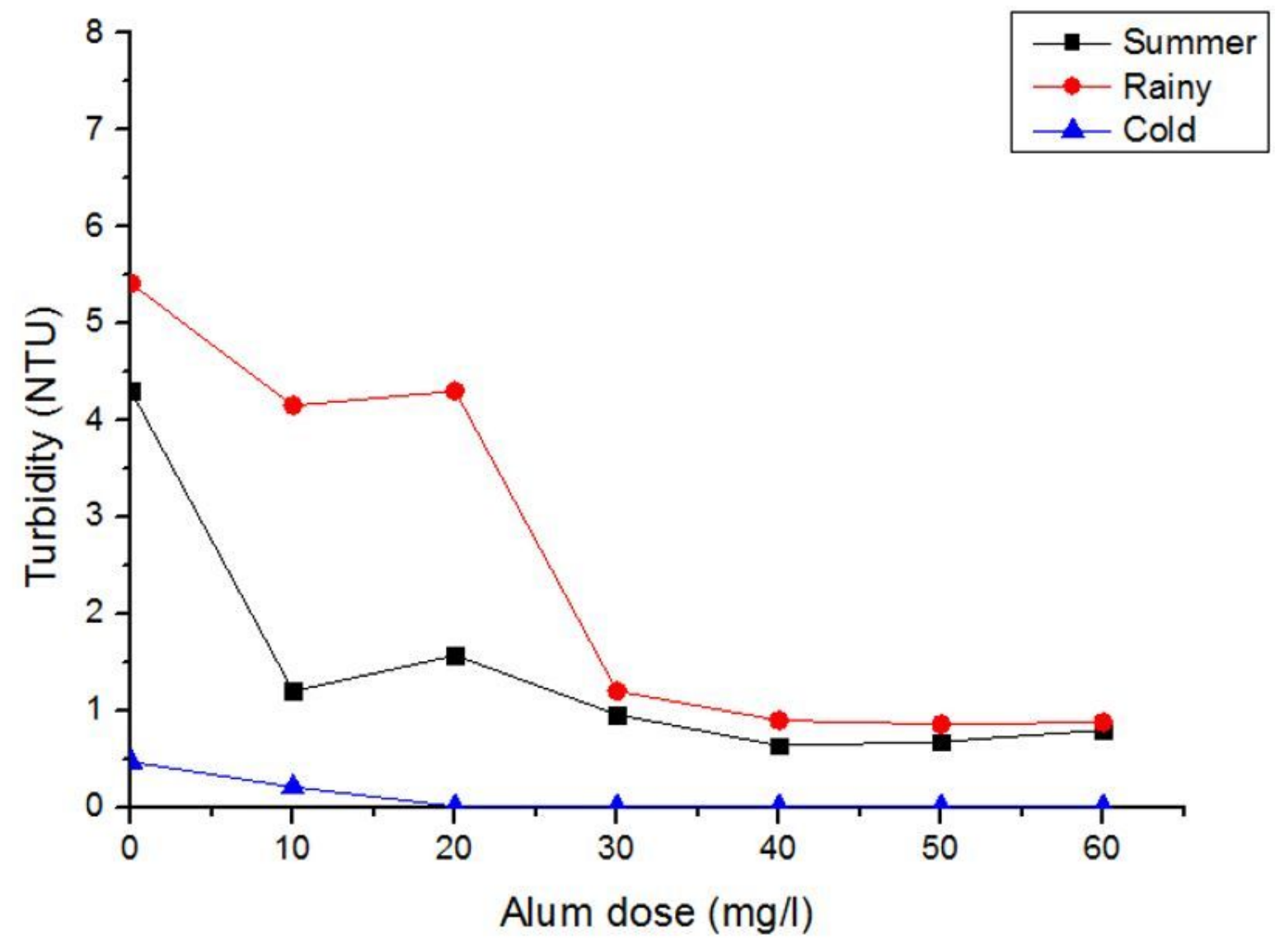

Figure 2

Jar test of mountain water from Karen village 


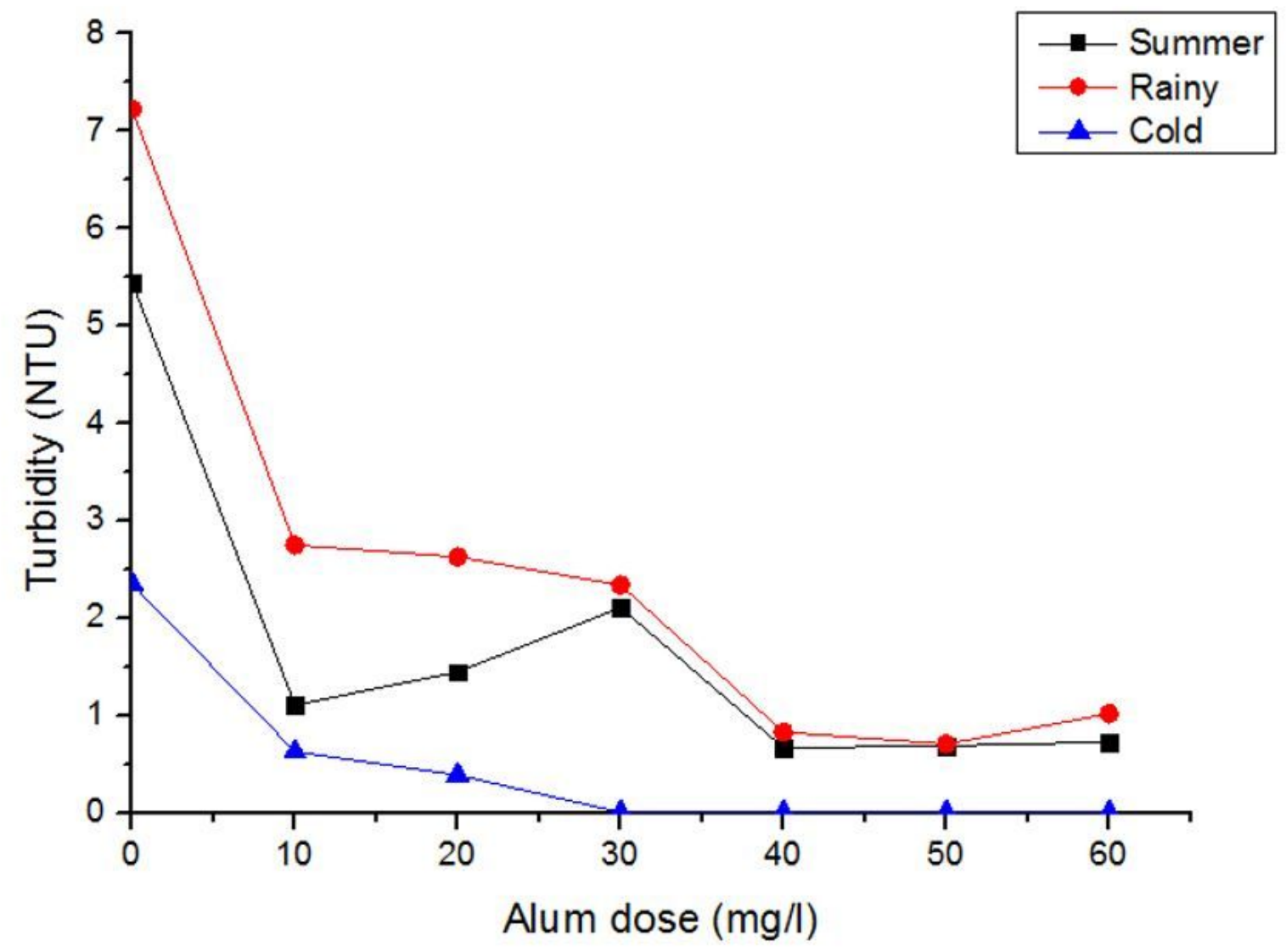

Figure 3

Jar test of mountain water from Lahu village 


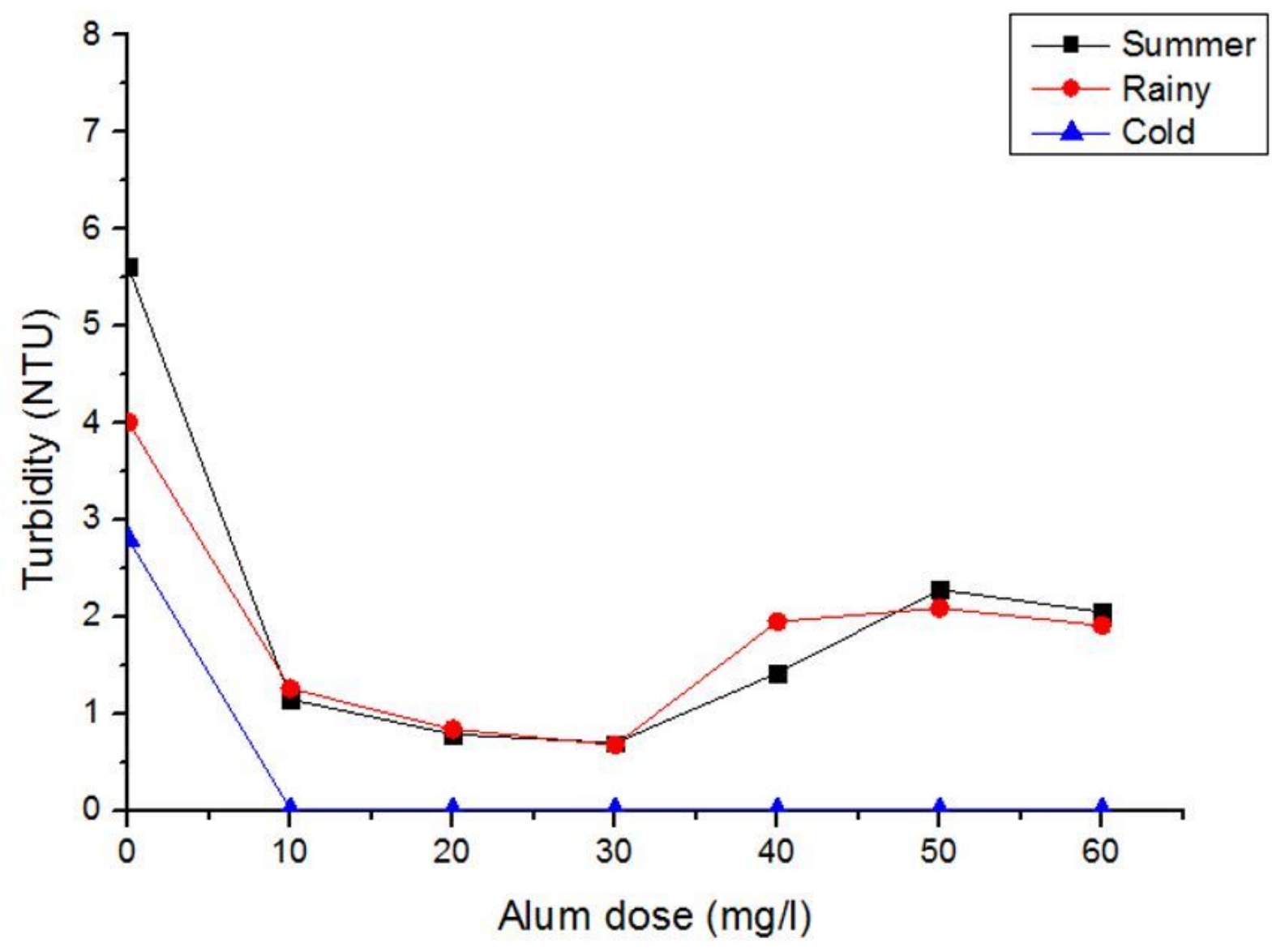

Figure 4

Jar test of mountain water from Lisu village 


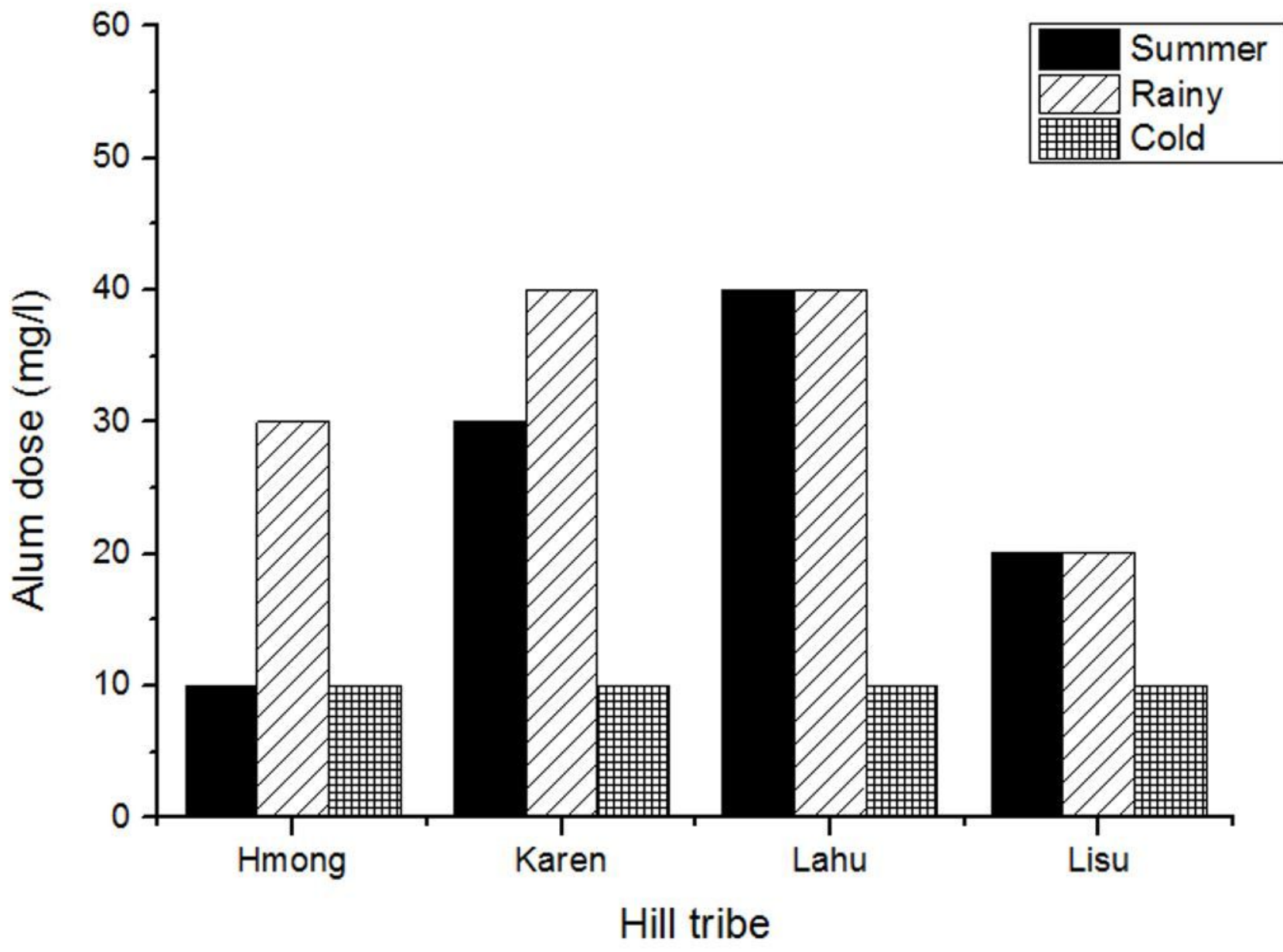

Figure 5

Estimation of optimum alum does of raw water in three seasons from hill tribe village.

\section{Supplementary Files}

This is a list of supplementary files associated with this preprint. Click to download.

- GraphicalAbstract.jpg 